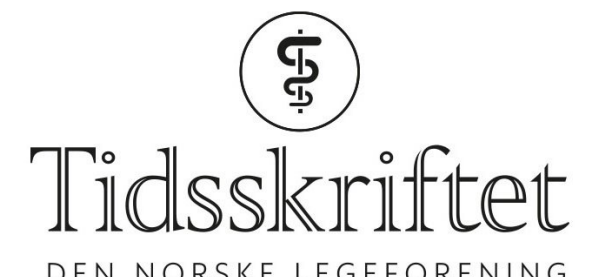

DEN NORSKE LEGEFORENING

\title{
Hva jeg tenker på når jeg tisser
}

GJESTESKRIBENT

JAN CHRISTOPHER NAESS

Forfatter

Det hadde seg slik at jeg tisset så ofte og så lite om gangen at det var til stor muntrasjon og irritasjon for de nærmeste, og for meg også.

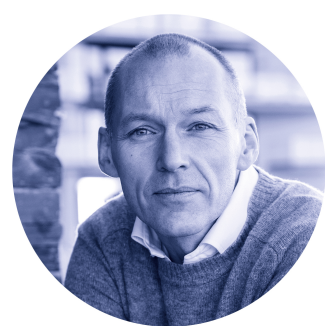

Foto:Julie Pike

Charles Bovary er ingen ambisiøs lege, og derfor er det ikke han som finner på at han skal lese seg opp innen kirurgisk metodikk og utføre en krevende operasjon på klumpfoten til stallgutten Hippolyte. Nei, her er det hustruen Emma som ønsker å sole seg i glansen av en mann (i dette tilfellet ham hun er gift med).

Det går selvfølgelig galt. Dr. Bovary kutter over pasientens akillessene, og noen uker etter inngrepet må Hippolyte utstyres med et protesebein. Men ikke uten først å ha fått oppleve å våkne opp etter en operasjon og erfare at ting ikke er blitt akkurat slik han ble forespeilet.

Også jeg har vært under kniven.

Tissingen var mest irriterende for min del, det må jeg vel si. Ikke minst om jeg for eksempel delte tomannstelt med en kompis, og det var kuldegrader i fjellheimen. Du klarer å holde deg, nei, jeg klarer ikke å holde meg! Soveposeglidelås, teltglidelås, fikling med fjellstøvler, teltduk. Faen, så kaldt! Tisse. Ferdig allerede? Teltduk, fomling med fjellstøvler, teltglidelås, soveposeglidelås. Du klarer å holde deg, nei ... osv. osv. Det er ikke bare seg selv man belaster når man er i en sånn forfatning.

Kinobesøk, besøk i sin alminnelighet, møter, undervisning, bussturer som strakte seg over flere enn seks holdeplasser: Alt var en prøvelse.

Prøvelsene pågikk i 15 år, med jevn forverring. Man normaliserer sitt eget avvik og tenker at sånn er man bare.

Endelig var det noen som fikk meg til å oppsøke fastlegen. Han stakk fingeren i rumpa på meg og sendte meg videre til en lege som ba meg urinere på en seismograf før han beordret sin tiltrekkende unge assistent til å skyve en lang og krum metallstang gjennom uretra og et stykke inn i urinblæren min. Siden ble jeg sendt til en mann i hvit frakk som skrøt av at han 
var en av verdens dyktigste kirurger til å blokke ut og fikse sånne ødelagte urinpassasjer. Han ville imidlertid gjøre meg oppmerksom på at jeg kom til å forlate operasjonssalen utstyrt med et midlertidig kateter. To uker med kateter, og så blir livet ditt forandret, sa han.

Dagen etter våknet jeg alene i et sykehusværelse, og da det langsomt demret for meg hvor jeg var, senket jeg blikket. Jeg blunket. Jeg blunket igjen. Ut av et hull i nedre del av buken stakk et gjennomsiktig rør, og der skulle det verken ha vært hull eller rør. Utlagt tarm, tenkte jeg mens redsel og bitterhet kjempet om overtaket i alt som kan kalles meg.

Kort tid etter satt verdens dyktigste kirurg ved sengen min og forklarte at en uforutsett omstendighet hadde oppstått under inngrepet og tvunget ham til å avbryte underveis. Det artige røret var en midlertidig løsning som skulle gjøre det mulig å late vannet de neste seks til 12 månedene, mens jeg ventet på en ny åpning i operasjonskøen.

Heldigvis ordnet det seg raskere enn fryktet, og bare et par måneder senere kunne jeg reise på en to ukers forfatterturné i grunnskolen i Trøndelag - riktignok med urin (og en del blod) i en plastpose teipet fast rundt leggen, men i alle fall med røret der det hørte hjemme. Jeg tror ikke ungene tok skade på sin sjel av at jeg hadde en litt underlig gange.

Hvor vil jeg med alt dette?

Først vil jeg si at det er herlig å kunne late vannet i visshet om at det blir mange timer til neste gang jeg trenger å gjøre det. Flere år senere føler jeg meg fortsatt som en fri mann hver gang jeg går på do. Og det vil jeg takke verdens beste kirurg for. Ja, det var han som foretok det andre inngrepet også.

Dernest tar jeg hele opplevelsen som en påminnelse om at vi ikke kan gardere oss mot uforutsette omstendigheter. Alt vi kan, er å plassere oss på en skala som går fra bitter bebreidelse til stoisk ro. Jeg anbefaler sistnevnte, men frykter at jeg lett bikker mot førstnevnte.

Til sist er dette en anledning til å gå i meg selv som forfatter. Det er lett å gjøre som Flaubert og søke lesernes gunst ved å latterliggjøre leger som representanter for en inkompetent, golfspillende, materialistisk og selvgod stand. En god forfatter bør imidlertid ikke glemme hvor mange små og store lidelser vi er blitt befridd for takket være nettopp legene.

Det tenker jeg på hver gang jeg tisser.

Publisert: 4. september 2017. Tidsskr Nor Legeforen. DOI: 10.4045/tidsskr.17.0587

(C) Tidsskrift for Den norske legeforening 2020. Lastet ned fra tidsskriftet.no 